\section{Argemone ochroleuca SWEET (PAPAVERACEAE) - A NEW INVASIVE SPECIES IN ANDHRA PRADESH STATE}

\section{Sudhakar Reddy ${ }^{1}$ and Chiranjibi Pattanaik ${ }^{2}$}

${ }^{1}$ Forestry and Ecology Division, National Remote Sensing Agency, Hyderabad, Andhra Pradesh 500037, India

2 Salim Ali Centre for Ornithology and Natural History, Deccan

Regional Station, Hyderabad, Andhra Pradesh 500017, India

Email: ${ }^{1}$ csreddy_nrsa@ rediffmail.com; ${ }^{2}$ jilu2000@ rediffmail.com (corresponding author)

plus web supplement of 1 page

Critical examination of flora of Hyderabad city revealed the existence of not only Argemone mexicana L., but also another neotropical invasive species of Argemone L. It was collected from the wastelands of Begumpet and Balanagar area in Hyderabad district, Andhra Pradesh and was been identified as Argemone ochroleuca Sweet. This species has never been recorded from Andhra Pradesh. Therefore, a brief note on its extended distribution, phenology and habitat with supplemented photographs of the specimen is provided here. A comparative study with Argemone mexicana L. is also given in Table 1.

Argemone ochroleuca Sweet Brit. Fl. Gard. 3: t. 242. 1829; Ownbey in Mem. Torr. Bot. Club 21(1):1-149. 1958; Maheswari, Fl. Delhi:55. 1963; Nair in Rec. Bot. Surv. India 21(1): 7-8. 1978; Debnath and Nayar, Fl. India 2:5. 1993. (Papaveraceae).

Erect annual herb, up to $50 \mathrm{~cm}$ tall. Young stems whitishpurple or violaceous. Leaves oblanceolate, semiamplexicaul, sessile at base, sinuate to pinnatifid, basal leaves deeply lobed; lobes oblong, glaucous. Flower buds oblong, 8-15 x 4-9mm; flower is whitish or pale lemon yellow, $2.5-3.5 \mathrm{~mm}$ across, sessile, subtended by $2-3$ foliaceous, $2-5 \mathrm{~cm}$ long, ca $5 \mathrm{~mm}$ broad bracts. Sepals 3, 8-12 x 5-7mm. Petals 6, obcuneate-obovate, 28-30 x 16$19 \mathrm{~mm}$. Stamens many, $8-10 \mathrm{~mm}$ long; filaments pale yellow; anthers oblong, recurved, dark yellow. Ovary 8-10 x ca 5mm; stigmas five-lobed, deeply dissected, dark red. Capsules ovoid or lanceolate-ovoid, $1-4 \mathrm{~cm}$ long excluding style, 4-17 mm thick, with 12-26 erecto-patent spines per valve, the largest spine up to $10 \mathrm{~mm}$ long; seeds 1.5-2mm in diam., finely reticulate, black (Image $1^{\mathrm{w}}$ ).

Specimens examined: Flowers and fruits, 18.v.2005, along the railway track, Begumpet, Hyderabad district, Andhra Pradesh; flowers, 25.v.2006, wastelands, Balanagar, Hyderabad district, Andhra Pradesh (Kakatiya University Herbarium - KUH, Warangal). June.

Phenology: Flowering and fruiting between February and

Habitat: A weed found along railway tracks, open fields and wastelands. It is associated with Argemone mexicana L. and Alternanthera tenella (another invasive exotic species).

Remarks: This species is native of Mexico. In India, it is found in Punjab, Delhi (Maheswari, 1963) and Uttar Pradesh. This species was recorded for the first time from southern India (Ganesh Babu et al., 2006). Why it has not been recorded from Andhra Pradesh so far can be ascribed to two reasons. First, it is quite difficult to distinguish $A$. ochroleuca Sweet from $A$. mexicana L. in pressed condition (Ownbey, 1958). Second, the species is
Table 1. Distinguishing characters of A. mexicana L. and A. ochroleuca Sweet

\begin{tabular}{|c|c|c|}
\hline Characteristics & A. mexicana L. & A. ochroleuca Sweet \\
\hline Plant body & Green, slightly glaucous. & $\begin{array}{l}\text { Whitish-green, densely } \\
\text { glaucous with reddish tinge. }\end{array}$ \\
\hline Stem prickles & $\begin{array}{l}\text { A few per unit area }(0-6) \text {, } \\
\text { nearly straight at the base } \\
\text { of stem, } 3-4 \mathrm{~mm} \text { long. }\end{array}$ & $\begin{array}{l}\text { more per unit area }(0-8) \text {, bent } \\
\text { downward at the base of } \\
\text { stem, } 5-6 \mathrm{~mm} \text { long. }\end{array}$ \\
\hline Leaves & $\begin{array}{l}\text { spreading, bent downward, } \\
18-28 \mathrm{~cm} \text { long, } 5-10 \mathrm{~cm} \text { broad, } \\
\text { lobes } 1.2-5.6 \mathrm{~cm} \text { broad }\end{array}$ & $\begin{array}{l}\text { not spreading, not bent, } 16- \\
22 \mathrm{~cm} \text { long, } 4-8 \mathrm{~cm} \text { broad, } \\
\text { lobes } 1-5.3 \mathrm{~cm} \text { broad. }\end{array}$ \\
\hline Flower buds & $\begin{array}{l}\text { subspherical, prickles } \\
\text { many, green. }\end{array}$ & $\begin{array}{l}\text { Oblong, prickles few, tinged } \\
\text { red. }\end{array}$ \\
\hline Flowers & bright yellow & light lemon yellow \\
\hline Sepal horns & $\begin{array}{l}6-10 \mathrm{~mm} \text { long, } 4-5 \mathrm{~mm} \text {, } \\
\text { broad at base }\end{array}$ & $\begin{array}{l}6-8 \mathrm{~mm} \text { long, } 2-3 \mathrm{~mm} \text { broad } \\
\text { at base. }\end{array}$ \\
\hline Petals & 6 & 6 , rarely 9. \\
\hline Stigmatic lobes & $\begin{array}{l}\text { broad, closely crowded } \\
\text { together and appressed to } \\
\text { the style }\end{array}$ & $\begin{array}{l}\text { narrow, spreading widely and } \\
\text { revealing the non-receptive } \\
\text { surfaces between them }\end{array}$ \\
\hline Capsule & $\begin{array}{l}\text { oblong, prickles on capsule } \\
\text { not spreading, } 3.9 \times 1.5-5.2 \\
\text { x } 1.9 \mathrm{~cm} \text {; seeds deep brown }\end{array}$ & $\begin{array}{l}\text { Lanceolate-ovoid, } 1-4 \mathrm{~cm} \text { long } \\
\text { excluding style; seeds black }\end{array}$ \\
\hline $\begin{array}{l}\text { Chromosome } \\
\text { number }\end{array}$ & $2 n=28$ & $2 n=28,56$ \\
\hline
\end{tabular}

known from mostly northern most states of India (Debnath \& Nayar, 1993). Venkatesh (1962) recorded A. ochroleuca Sweet for the first time from India and quoted that "if allowed for sufficient time, it may become as widespread as $A$. mexicana $\mathrm{L}$. (Image $2^{\mathrm{w}}$ ) in the country". The white flowered $A$. ochroleuca Sweet was earlier regarded as only a mutant of the yellow flowering $A$. mexicana $\mathrm{L}$. (Malhotra, 1960). The most distinguishing features of the two species are the shape of flower buds, stigmatic lobes and the colour of petals (Kshetrapal et al., 1984). Our detailed comparative studies have shown that there are some other vegetative features in which the two species differ. Table 1 summarizes the important differences between the two species.

\section{REFERENCES}

Debnath, H.D. \& M.P. Nayar (1993). Flora of India, Vol. 2, Sharma, B.D. \& N.P. Balakrishnan(eds.). Botanical Survey of India, Calcutta, pp.5-6.

Ganesh Babu, N.M., R. V. Sankar, K. Ravikumar \& D.K. Ved (2006). Notes on some interesting and noteworthy plants from Southern India, Journal of Economic and Taxonomic Botany 30: 390-393.

Kshetrapal, S., U. Jain \& T.C. Tanwar (1984). Anatomical studies in the genus Argemone. Bulletin of the Botanical Survey of India 26: 164-166.

Maheswari, J.K. (1963). The Flora of Delhi, pp.55-56. Council of Scientific and Industrial Research, New Delhi.

Malhotra, S.K. (1960). Natural hybrid between Argemone mexicana and $A$. ochroleuca. Current Science 29: 282.

Ownbey, G.B. (1958). Monograph of the genus Argemone for North America and West Indies. Memoirs of the Torrey Botanical Club 1: 1-149.

Venkatesh, C.S. (1962). Argemone ochroleuca Sweet sub sp. ochroleuca, A new record for India. Current Science 31: 250-251.

\section{ACKNowledgements}

Authors are thankful to Dr. M.S.R. Murthy, Head, Forestry and Ecology Division, National Remote Sensing Agency, Hyderabad and Dr. S.N. Prasad, Senior Principal Scientist, SACON, Deccan Regional Station, Hyderabad for their encouragement and providing facilities to carry out this work. Thanks to Dr. V.S. Raju, Department of Botany, Kakatiya University, Warangal for giving valuable comments on this paper.

${ }^{w}$ See Images in the web supplement at www.zoosprint.org

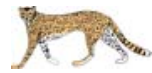

Manuscript 1730; (C) ZOO; Date of publication 21 November 2007 Received 05 March 2007; Revised received 08 October 2007; Finally accepted 11 November 2007 